IZABEL ANDRADE MARSON

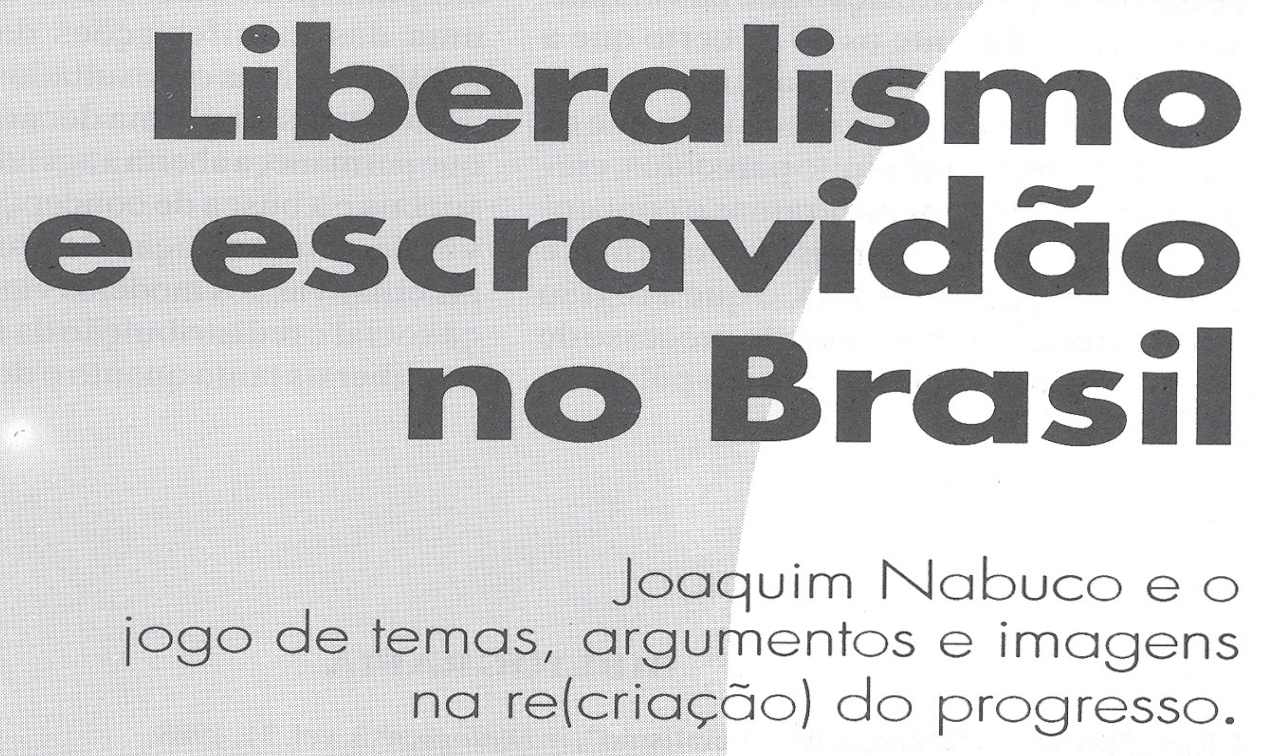

O estudo do tema Liberalismo e Escravidão no Brasil impõe ao historiador a passagem obrigatória pelos textos de Joaquim Nabuco, não apenas porque foi o mais conhecido analista do liberalismobrasileiro no séculoXIX, mas sobretudo porque se tornou uma fonte histórica para todos os autores que abordaram a história do Brasil daquele século.

A necessidade de conciliar um tema tão complexo com as limitações de um artigo obrigou-nos a recortar uma fase na trajetória deste autor - 1878 a 1885 -, momento particularmente criativo, pois nele Nabuco construiu uma teoria sobre a escravidão brasileira, envolveu-se em disputadas campanhas eleitorais, destacou-se no Parlamento e redigiu sua obra mais divulgada, $O$ 
"(...) Inteiramente absorta na produção de riqueza e na concorrência pacifica, a bsociedade burguesa não mais se apercebia de que fantasmas dos tempos de Roma haviam velado o seu berço. Mas, por menos heróica que se mostre hoje a sociedade, foi não obstante necessário heroísmo, sacrificio, terror, guerra civile batalhas de povos para torná-la uma realidade. E nas tradiçôes classicamente austeras da República romana, eus gladiadores encontram os ideais e as formas de arte, as ilusóes de que necessitavam para esconderem de si próprios as limitaçôes burguesas do conteúdo de suas lutas e manterem seu entusiasmo no alto nivel da tragédia histórica" (Karl Marx, O Dezoito Brumário de Luís Bonaparte).

“(..) A politica (...) tem lados ainda indefinidos que confinam com a arte, a religião a

e a filosofia, isto é, para falar a linguagem hegeliana, com as três esferas em que se manifesta o espirito do mundo"

(Joaquim Nabuco, Minha Formação) (1).

IZABEL ANDRADE MARSON é professora do Departamento de História da Unicamp.

1 K. Marx, "O Dezoito Brumário deLuísBonaparte", in Manus critos Econômica-Filosóficos e Outros Textos Escolhidos Seleção de José Arthur Glannotti, Trad. José Carlos Bruni (etalii), $2^{4}$ ed., São Pau10. Abril Cultural, 1978 , p. 330 J. Nabuco, MinhaFormacáo Intr. de Gilberto Freyre. Brasilia, Ed. da Univ. de Brasilia, 1963, p. 78 
Abolicionismo (2). Seu empenho na emancipaçâo dos escravos constituiu uma das exteriorizações da intensa turbulência política vivida no Império nodecênio 1878-88. Tal agitaçâo pode ser percebida também na realizaçāo de dois Congressos Agrícolas em 1878 (um no Rio de Janeiro e outro no Recife), expressōes das discordâncias entre os agricultores doSul e do Nordeste na resoluçảo da "crise da lavoura", no confronto de projetos para a questảo servil, na experimentação de uma reforma eleitoral $\mathrm{e}$ na instabilidade política explícita nas dissoluçōes que atingiram a Câmara e vários Gabinetes.

Oprincipal objetivo desta reflexãoé justamente esclarecer olugar das proposiçōes de Nabuco neste embate, destacandosua historicidade e as dimensōes políticas da complexa teia argumentativa por ele criada para justificar a incompatibilidade entre liberalismoc escravidão.

\section{MONOPÓLIO E ESCRAVIDÃO}

"Assim como a palavra Abolicionismo, a palavra Escravidāoć tomada neste livro em sentido lato. Esta nāo significa somente a relação do escravo para com o senhor; significa muito mais: a soma do poderio, influéncia, capital, c clientela dos senhores todos; o feudalismo estabelecido no interior; a dependência em que o comércio, a religiâo, a pobreza, a indústria, o Parlamento, a Coroa, o Estado enfim, se acham perante o poder agregado da minoria aristocrática, $\mathrm{em}$ cujas senzalas centenas de milhares de entes humanos vivem embrutecidos e moralmente mutilados pelo próprio regime a que estâo sujeitos(...)"(3).

Qual o conceito que Nabuco conferiu à escravidão? Eis a primeira indagação que o historiador se coloca ao ler $O A$ bolicionismo. E, ao procurar respondê-la, depara-se com um termo que possuía, ao mesmo tempo, um sentido abrangente e muitos outros significados particulares. Osentido primeiro e o que exerce maior impacto sobre oleitor é ode uma relaçāo humana "bárbara e má" que vitimou o escravo, criatura que vivia sob o domínio quase absoluto do senhor. O escravo era um "refém", uma "vítima indefesa", um "oprimido que não sentia ódio e que foi capaz de suportar 300 anos de escravidão sem ter sua alma azedada por ela"; um ser que possuía a "consciência adormecida", "o coraçâo resignado", "a esperança morta". "Órfão do destino" que "só tem de seu a morte"; uma classe sem direito algum (de desobedecer, de ter asilo inviolável), que sofria penas já abolidas, como "os açoites e a tortura". A natureza da escravidão no Brasil, em 1883, era a mesma havia 300 anos: estava intrinsecamente relacionada aos atributos morais do senhor (4).

“(...) e não é mais branda do que em qualquer outro país da América. Se ela assim parece, é porque os escravos aqui sảo mais resignados, pois o limite da crueldade do senhor está na passividade do escravo porque desde que a passividade cesse a crueldade aparece"(5).

Porém, o escravo poderia, em situaçōes de desespero, transformar-se num agressor; nestes momentos, o senhor ficava à sua mercê e se tornava também uma vítima. Isso porque a escravidão era "um estado violento no qual nāo pode deixar de haver uma explosão. Ela expōe continuamente o senhor ou os seus agentes e tenta o escravo aocrime". Por isso, não estava entre os objetivos abolicionistas insuflar os escravos, para nāo expor a classe mais influente e poderosa do Estado à "vindita bárbara e selvagem de uma populaçăo mantida ao nível dos animais e cujas paixôes, quebrado o freio do medo, não conheceria limites. (...) É a escravidâo que é má e obriga o senhor a sê-lo" (6).

A escravidão era "barbáric" c crime, uma ilegalidade perante odireito internacional e a legislaçẩobrasileira. O tráfico no continente africano-a origem da escravidāo no século

2. Nabuco, O Abolicionismo Ints. de Marco Aurtio Nogueira, $5^{*}$ ed, Petrdpolis. Vozes, 1988

3 idem, ibidem, p. 28.

4 Idem, ibidem, pp. 39-50, passim.

5 idem, ibidern, p. 102

6 idem, ibidern, pp. 39-40, 103
XIX - constituía um "contrabando de sangue", uma "perversidade" e um atentado contra o direitoque é a base da sociedade civilizada, "resultado" das conquistas do homem e da civilizaçăo na sua longa evoluçāo.

“De fato, a escravidāo pertence ao númerodas instituiçōes fósseis, e só existe em nosso periodo social numa porçāo retardatária do globo.(...)Como a antropofagia, o cativeiro 
da mulher, a poligamia, a escravidảo é um fato que nāo pertence naturalmente ao estádio a que chegou o homem"(7).

Se a legislação brasileira fosse cumprida, ela já teria sido superada. Pela lei de $7 \mathrm{de}$ novembrode 1831 (que decretou a ilegalidade dotráfico), todos os escravos chegados ao Brasil a partir daquela data deveriam ser declarados livres; portanto, a grande maioria dos cativos aqui existentes estava ilegalmente na escravidão. Por sua vez, a lei de $28 \mathrm{de}$ setembro de 1871 - pela qual "ogovernobrasileiro fezo mundo acreditar que a escravidâo havia acabado no Brasil" - poderia ter garantido, entre outros direitos, a liberdade a todos os filhos de escravas nascidos depois da lei. Porém, a primeira determinaçẩo nunca fora respeitada, e a segunda, devido a suas "imperfeiçöes", desvirtuou-se completamente. Assim, conclui Nabuco, a escravidão no Brasil continua existindo comosempre existiu; ela nảo só năo acabou como nâo mudou com a lei, a causa nāo está vencida: a alforria e o resgate pela emancipaçīo existem para poucos. Permanecem a mortalidade de escravos, o númerode africanos em cativeiro, a caçada aos negros fugidos, a educaçâodos ingênuos na escravidão, a existência dos "ergástulos agrários" e os anúncios nos jornais. AConstituição nâose ocupou dos escravos, por isso eles continuam fora da lei. A maior "chaga" da escravidăo era a "violaçâo da lei", a existência de toda uma sociedade vivendo à sua revelia, obrigando os estadistas a criarem meios de validar os africanos escravizados ilegalmente, a reduzir reféns estrangeiros à escravidão e de torná-los propriedade legítima (8). Etudo isso para atender à avidez de traficantes inescrupulosos e imorais e a uma classe influente e poderosa do Estado:

“É curioso que os sent ores, que exercem esse poder ilimitado sobre seus escravos, consideram uma opiessão intolerável contra si a mínima intervençío da lei a favor destes. A resistência que a lavoura opỏs à parte da lei de 28 de setembro que criou o direito do escravo de ter pecúlio próprio e ode resgatar-se por meiodeste, prova que nem essa migalha ela queria deixar cair da sua mesa. Os lavradores do Bananal, por exemplo, representando pelos seus nomes a lavoura de S. Paulo e dos limites da província do Rio, diziam em uma petição às Cämaras: 'Ou existe a propriedade com suas qualidades essenciais, ou entāo nãopode decididamente existir. A alforria forçada é a vindita armada sobre todos os tetos, a injúria suspensa sobre todas as famílias, $o$ aniquilamentoda lavoura, a morte do país"(9).

A escravidão desafiava a lei, o Estado e a cidadania:

“(...) É a posse, o domínio, o seqüestro de um homem - corpo, inteligència, forças, movimentos, atividade que só acaba com a morte. Comose há de definir juridicamente o que o senhor pode sobre o escravo, ou o que este pode sobre o senhor? Em regra o senhor pode $t u d o(. .$.$) ; é monopólio da terra, do Capital e do trabalho, um Estadodentro$ do Estado, cem vezes mais forte do que a própria naçáo" (10).

Enquanto monopólio da terra, a escravidāodeu origem à grande propriedade territorial com "trabalhadores enclausurados" e "proletários sem um pedaçode terra", dependentes e miseráveis, verdadeiros "servos da gleba". Além disso, esgotou o solo, criou uma populaçáo de "nòmadas", aviltou o trabalho, estiolou as vilas do interior, criou uma riqueza estéril (porque reaplicada cm escravos c noluxo) e efèmera, c impediu odesenvolvimentoda indústria e do progresso:

"O caráter da sua cultura é a improvidência, a rotina, a indiferença pela máquina, o mais completodesprezo pelos interesses do futuro, a ambiçäode tirar o maior lucro imediato com o menor trabalho possível, qualquer que seja o prejuizo das geraçōes seguintes. O parcelamento feudal do solo que cla instituiu, junto ao monopólio do trabalho que possui, impede a formação de núcleos de população industrial c a extensăo do comércio no interior. Em todos os sentidos foi ela, e é, um obstáculo ao desenvolvimento material dos municipios: explorou a terra sem atenção à localidade, sem reconhecer deveres para com o povo de fora de suas porteiras; queimou, plantou e abandonou; consumiu os lucros na compra de escravos e no luxo da cidade; náo edificou cscolas,

7 idem, ibidern, p as

Idem, ibidem, DP 45.97.

passin.

9 ligem ioden a. 101

10 ldem iodem of so 34 


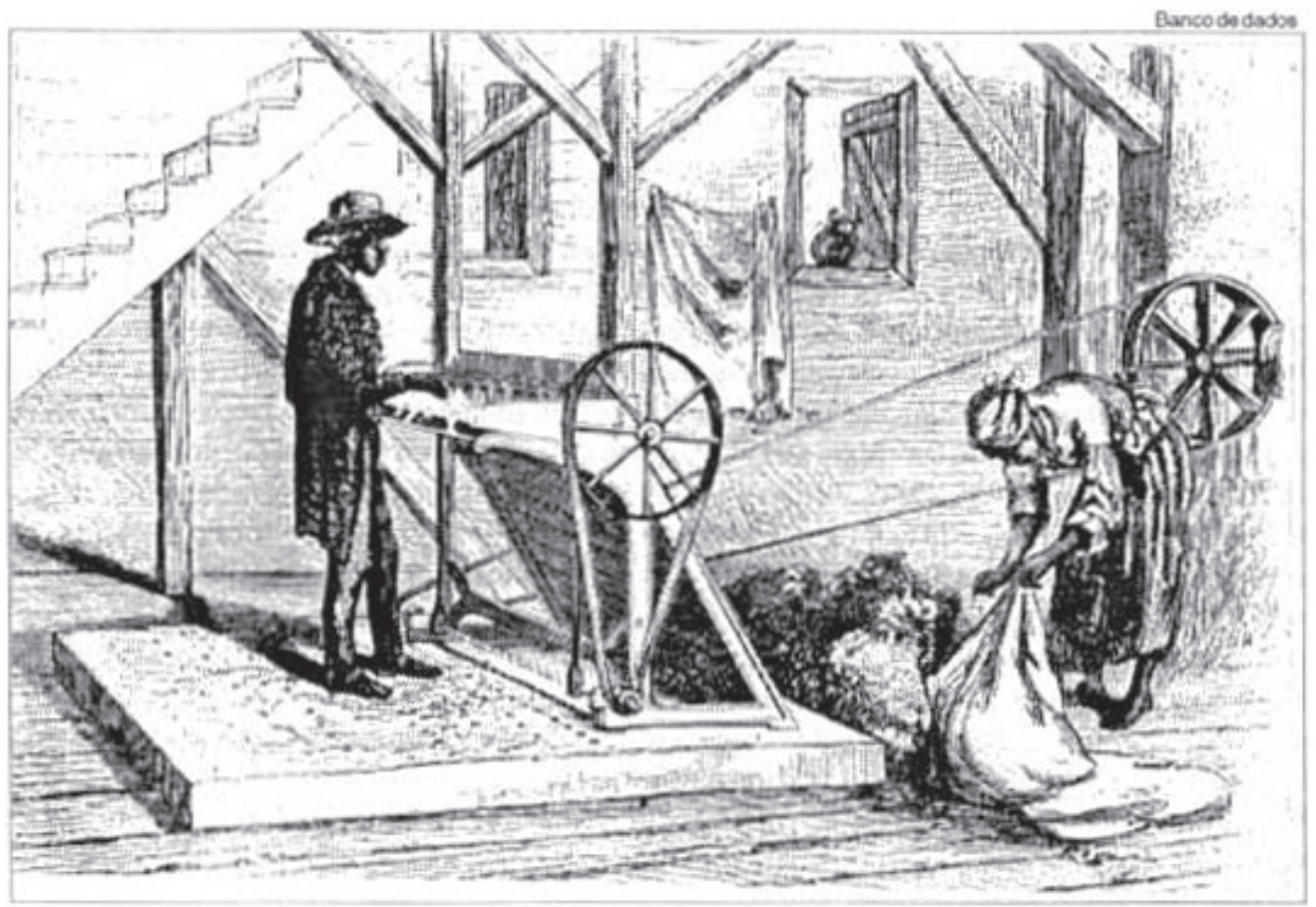

nem igrejas, náo construiu pontes, nem melhorou os rios; (...) nâo fomentou nenhuma indústria, nảo empregou máquinas, nảo concorreu para o progresso da zona circunvizinha"(11).

Ainda, atrofiou o comércio, ao torná-lo dependente dos "correspondentes" e dos proprietários de escravos. "Agentes da escravidão", os correspondentes "compram tudo o que ela thes oferece e vendem-Ihe tudo o que ela precisa". Sua hegemonia nāo abre horizontes ao país, não cria consumidores, rejeita o progresso, torna o comércio servode uma classe (12).

Do monopólio da terra, do trabalho e do comércio decorreu o monopólio social da escravidão. Ela moldou uma sociedade sem ordem c com desenvolvimento retardado. formada por "algumas familias transitoriamente ricas" e "dez milhōes de proletários" (13). Odesenvolvimento social do Brasil foi oposto ao ocorrido nos Estados Unidos. Ĺ́ a escravidão nấo afetou a constituiçâo social porque "manteve a parte superior do organismo intacta" cos negros ficaram fora da sociedade. Aqui, todavia, ela foi mais hábil c nảo desenvolveu a prevenção da cor, nem "uma divisão fixa de classe". No dia seguinte à alforria, o cscravoé um cidadáo igual a qualquer outro, pode mesmo comprar escravos, casar com livres, criando assim uma "confusỉo de classes", um "caosétnico", uma "síntese nacional" que "degradou as classes" (14). Impediu a formação de pequenas propriedades e de uma "classe média". Tornou lavradores e moradores "proletários" sem "independência de ordem alguma vivendo ao azar do capricho alheio"; não consentiu na formaçăo de classes operírias; fez crescer artificialmente o contingente de empregados públicos e tornou-os "servos da gleba do Estado"; dificultou a constituiçāo de uma verdadeira aristocracia, pois "a aristocracia territorial náo é nem aristocracia do dinheiro, nem de nascimento, nem de inteligência, nem de raça"; e neutralizou as forças sociais: cooptou a lgreja, degenerou o patriotismo("ser patriota é ser escravagista"), repeliu a imprensa e a cscola, c impediu a emergência da opinião pública (15).

A escravidăo, e seus "ergástulosagrários", “um Estadodentrodo Estado", desvirtuou oliberalismoe a monarquia parlamentar, e engendrou uma "paródia de democracia", uma "nação sem povo" e sem vontade nacional. Degenerou os partidos, tornando-os veículos de interesses e ambiçōes pessoais; fez do sistema representativo um "enxerto de formas parlamentares num governo patriarcal", onde ministros, senadores e deputados vivem subjugados pelo poder pessoal do Imperador absoluto "comoo Czar e o Sultảo", ainda que se veja no centro de um governo moderno e provido de todos os órgãos superiores, como 
o Parlamento, oque o torna antes "um Primeiro Ministro Permanente do Brasil"(16).

Assim, noscu sentido mais abrangente, a escravidāo era um monopóliodo trabalho, da terra, docapital e do poder, "uma instituiçāo que forma um Impériodentrodo Império", um sucedâneo nacional do Antigo Regime (17).

\section{ABOLICIONISMO E LIBERALISMO}

"Vêde também que forças nós criamos! (...) vêde que ressuscitamosoespíritopúblico e que o país inteiro estremece de esperança como que nas vésperas de uma segunda independéncia.(...)

Conservar oquê? O que é que neste país nảo carece de reforma radical?(...) O periodo atual nãoé de conservaçâo, é de reforma, táo extensa, tão larga e tāo profunda que se possa chamar Revoluçâo; de uma reforma que tire este povodo subterrâneo escuroda escravidão onde ele viveu sempre, $\mathrm{e}$ lhe faça ver a luz do século XIX. Sabeis que reforma é essa?(...)é uma lei de abolição que seja também uma lei agrária (...)"(18).

"A propaganda abolicionista, com efeito, nâose dirige aos escravos. Seria uma cobardia inepta e criminosa, e, além disso, um suicídio político para o partido abolicionista, incitar à insurreição, ou ao crime, homens sem defesa (...). A escravidão não há de ser suprimida no Brasil por uma guerra servil, muito menos por insurreiçôes ou atentados locais (...). A emancipaçîo há de ser feita, entre nós, por uma leique tenha os requisitos, externos e internos, de todas as outras (...). A propaganda abolicionista é dirigida contra uma instituiçió e nảo contra pessoas. Não atacamos os proprietários como indivíduos, atacamos odomínio que exercem e o estado de atraso em que a instituição que representam mantém o pais todo" (19).

A desconstrução de uma instituiçáo de origem política e de toda a sua obra deveria também acontecer no campoda política. Por isso, "o Abolicionismo" se constituiu num projetode reforma e de emancipaçấo da naçâo do monopólio da escravidâo, uma "segunda dependência", a ser realizada por um partido político, noâmbitodo Parlamento, por meio de leis. Seria uma reforma que se transfiguraria em revoluçâo. Da desmontagem de um "sistema de leis concebidas pelo monopólio da escravidão" resultaria uma naçáo de cidadãos disciplinados e morigerados, "uma pátria comum, forte e respeitada, os membros agora em conflito todos em comunháo com os outros e consigomesmos: os escravosque agora estavam fora dogrẻmio social; os senhores, agora atacados como representantes de um regime condenado; os inimigos da escravidão; e a massa inativa da populaçáo, vítima do monopólio da terra e da maldiçâo do trabalho"(20).

Sua atuação projetar-se-ia no presente e no futuro. No presente, empenhava-se na promulgação de duas leis. A primeira, de emancipaçâo dos escravos existentes, uma concepçâo nova de abolicionismo que suce dia a "idéia de suprimir a escravidão entregando-Ihe um milhaio e meio de escravos de que cla se achava de posse $\mathrm{cm} 1871 \mathrm{c}$ deixandoa morrer com eles"(21). A segunda, uma lei agrária, uma lei de"democratizaçiodo solo", que determinaria um imposto territorial a ser estabelecidosobre as terras incultas, de forma a obrigar seus proprietários a negociá-las, abrindo assim espaço para a pequena propriedade e, em consequiêneia, para a classe média (22).

Além dessa realizaçâo imediata, havia outra maior, a do futuro: "apagar os efeitos de um regime, que há três séculos é uma escola de desmoralizaçảo e inércia, de servilismo e irresponsabilidade para a casta dos senhores", assim como para os milhares de proletáriosque viviam à sua órbita. Seria um trabalho de regeneraçãodocorpoatrofiadoda naçäo, de construçāo da "igualdade social" (entendida como igualdade civil), particularmente para os "proletários", por intermédioda fórmula "Liberdade e Trabalho". Rebatendoa tese de que o Brasil necessitasse de imigrantes, em especial os chineses, argumentava Nabuco:

"Vêde bem, senhores, nós temos hoje de dez a doze milhōes de habitantes, população que vai sempre $\mathrm{cm}$ aumentoe cujos descendentes, entregue ela a si mesma, serão um dia cem milhōes. Pretende-se que essa população tem certos vícios, acusam-na de indolência, de incapacidade para otrabalhocontínuo, de indiferença pela propriedade c nâosei oque mais, e disso concluem que a salvação do Brasil está na imp̣ortação $\mathrm{cm}$
16 idem, itidem, pp. 139.9

17 Idem, ibidern, 34 Nabuco. "Conforb́neia no Teatro Politeama, A de Ja. nero (16es), in Conterin cas of 220 . Evta concec calo toi inspirada por Auguath Cochin que con. sider ava a escravidio im sos provitoces assepara. gos privepos assejura. sor peras meerpoles as co ionas" "peda principal do pacto colonial". A Cochin, L'Abolition de I'Esclavage. Font de France, Edsoons Desormeave 1970 (1" ed 1861) p 23 A Aecravdlocomoins 2al Aevolundso comoris datanbem por M. Sytva C Franco. Homens Livres na Ordem Escra-vocrats. Sto Pavio, IE B, 1964, = seus hames com o pacto colon: al foram analisados por Fernando A Novais. Port. gal - Glasil na Crise do gal o Brasil na Crise do Antigo Sistema Colonial (1777.1508), Sâo Paulo. Hucitec. 1978

18 I Nabuco, "Discurso num meetong Popular no Bairro de $\mathrm{S}$. Jose. Recite". 5.11 .1834 , in Contorinci as... PQ. 284-5

19 Idem, OAbolicioniemo . DP 39-4?

201 idem bisem, p. 92

21 idem, bidem, p. 25

22 t6en, "Discurso num meeting Popvar no Bairro des Jone- Apoto" in Confertnciat D. 285 
larga escala de uma raça que trabalhe sem intermitência (...). Quem já viu oproblema dos defeitos de uma raça ser solvido pela importação de outra? (...) Năo, senhores, o recurso da imigraçâo é muito importante, mas é secundário a perder de vista comparativamente a este outro: o de vincular ao trabalho, o de transformar pelo trabalho a nossa população toda. Se ela náo trabalha é porque nãopode ou porque nãoquer e a nossa tarefa é fazer que ela queira e que ela possa, criando a emulaçäo que lhe falta, se é porque ela não quer, destruindo os obstáculos - quaisquer que sejam - que se lhe opōem, se é porque ela não pode".

“(...)A liberdade sem o trabalho náo pode salvar este país da bancarrota social da escravidão nem tampouco merece o nome de liberdade; ́́ a escravidâo da miséria" (23).

Mas a tarefa mais ambiciosa do Abolicionismo se condensava num programa político-pedagógico de reeducaçẩo da elite política, visando a sua reconduçâo à prática do "verdadeiro liberalismo". Embora ainda nāo constituísse um partido ("era tấo-só uma agitação"), já obrigava conservadores, liberais e republicanos a revisôes significativas. Aos liberais, conseguira "pôr a descoberto os alicerces mentirosos do liberalismo entre nós", e a um grande número de republicanos, convencera de que sua obrigação mais urgente nảoera "mudar a forma dogoverno com o auxílio de proprietários de homens mas que a elevaçáo dos escravos a homens era tarefa que precedia toda a arquitetura democrática"(24). Em conferência proferida no TeatroSanta Isabel, no Recife, em 16 de novembro de 1884, ao mesmo tempoem que justificou suas posiçổes independentes em relação ao partidoe ao Gabinete Sinimbu, Nabucoexplicou que sua atuaçảoem favordo Abolicionismo no Parlamento(1879-81) fora uma demonstração dos fundamentos universais do liberalismo- liberdade c nacionalidade, princípios inscritos igualmente na história e na natureza humana:

“(...) só me isolei do partido para ficar fiel às idéias desse mesmo partido(...); nãose pode imaginar outro ministério mais oposto a tudo que constitui o liberalismo e o espírito democrático moderno.(...)A liberdade realizada pode ser um benefício e envolver a felicidade de um país, mas o que torna um povo livre é somente a aspiração pela liberdade, é o instinto, o sentimentoque faz com que ele se esforce e tudo sacrifique para adquiri-la c conquistá-la.

Um partido liberal que perde esta aspiraçãosente fugir-lhe a vida, é um organismo que sobrevive às suas funçôes, e entảo os seus elementos ativos, como se viu com os que foram engrossar o Partido Republicano(...). Senhores, a bandeira liberal é a mesma em todos os países, com a divergência natural que há entre o grau de civilização de cada um. (...)A bandeira liberal tem tidona história grandes transformaçöes(...), mas cla é ainda a mesma bandeira que Péricles arvorou no Pnyx, a mesma que os Gracos levantaram no Forum; é a bandeira da Reforma; do Édito de Nantes; (...) dos direitos do Homem. Em um país que luta pela sua independência, é a bandeira da nacionalidade; $\mathrm{em}$ um país que já chegou a grande desenvolvimento, é a bandeira das liberdades políticas (...). Éa bandeira, senhores, da emancipaçãodos servos da Rússia, assim como é a bandeira de Washington defronte os muros de Richmond. Em nosso país foi a bandeira da Inconfidência, a bandeira de 1817, a bandeira do Ipiranga, a bandeira do Ato Adicional, até que hoje volta a ser de novo a bandeira da Constituiçäo"(25).

Universal e eterno porque inscrito nos domínios da natureza, o "instinto/sentimento" liberal também se amoldava ao "grau de civilização", ou à historicidade de cada nação.

231 idem, Primeira Conferincia no Teatro Santa isabel". Re cile, 12.10 .1864 e Discurso no Monte Pio Pernam. bucano: 9.11 1804 in Con terkncis ....pe. 2540298

24iden OAbolcionimo, p. 31

25 ldem "Terceira Confertncis no Teatro Santa Irabei" 16.11 .1804 , in Conterdno. at Pp. 204, 207, $302-4$

26 idem bidem pe. $299-300$ góticas" ou as "Tábuas da Lei". Pelo contrário, assim como a natureza, precisavam ser maleáveis e capazes de incorporar as transformaçōes cobradas pelo progresso:

"A Constituiçâo é formaçẩo natural como o solo, onde camadas sucessivas se depositam (...), sujeita a eterno movimento c onde os erros que passam ficam sepultados sobre as verdades que nascem (...); cla é um grande mecanismo liberal, um maquinismo dotado de todos órgãos de locomoçẩo e de progresso, um organismovivo que caminha e se adapta às funçōes diversas que em cada época tem necessariamente que produzir" (26). 
Por tais motivos, a Constituiçáo brasileira poderia integrar a reforma/revolução descentralizadora. Ela permitiria mudanças que fariam com que os ministérios representassem os partidos, o governo fosse efetivamente de gabinete e nảo do presidente do Conselho, os grandes negócios do Estado fossem decididos em conferência de ministros e não em despacho imperial, o eixo parlamentar passasse pela Câmara e não pelo Senado vitalício, as províncias se vinculassem federativamente à União e, finalmente, com que fossem implantadas a eleição direta (com osufrágio estendido a todos os alfabetizados e com maior representaçảo das grandes cidades), a liberdade religiosa e a emancipaçāodos escravos sem indenização. Tudo isso resultaria no fim do "monopólio escravista" (27).

Moldadode acordo com os princípios clássicos da bandeira liberal, o Abolicionismo assumiu um duplosignificado. Enquanto prática universal, dava continuidade à obra dos grandes estadistas da história - Péricles, os Gracos, Lutero, os revolucionários franceses, Washington - e da história do Brasil - os Inconfidentes, os revolucionários de 1817, os Andradas, Evaristo da Veiga - no compromisso de construir a nação. Todavia, tinha também uma missāo histórica particular: a regeneraçāo da monarquia parlamentar no Brasil. Para isso, dispunha-se a uma intervenção imediata na história para abreviarotempo devida da escravidão (que, se deixada esgotar-se naturalmente, adentraria o século XX) e para desagregaros partidos existentes. Foi justamente esta missĩo que impeliu Nabuco a tecer os dois grandes temas de sua argumentação: o Abolicionismo c a Escravidão.

\section{O JOGO DE TEMAS, ARGUMENTOS E}

IMAGENS NA RE (CRIACÁO) DA LUTA

ABOLICION ISMOVERSUS ESCRAVIDAO

"Quando emprego a palavra escravidão, sirvo-me de um termo compreensivo-como é por exemploem França, a expressão Antigo Regime - dos resultados do nosso sistema social todo, o qual é baseado sobre a escravidão."

“(...) Mas nós representamos o espírito novo, espírito hoje tão profundamente radicado na sociedade brasileira comoestava antes da Independência: oespíritoda emancipação política (...), esse espírito que, quando os Inconfidentes foram abatidos $\mathrm{cm}$ Minas, levantou os revolucionários de $1817 \mathrm{~cm}$ Pernambuco, e quando estes subiram ao cadafalso inspirou triunfalmente os Andradas em S. Paulo. Sim, senhores, osentimento abolicionista está hoje táo enraizado no espírito e no caráter do nossopovocomo estava entâoo espírito da independência nacional" (28).

Abolicionismo e Escravidão são categorias complexas nío só porque resguardam múltiplos significados, mas especialmente porque nelas presente e passado se imbricam e projetam a imagem de um tempo síntese que confunde o universal e particular, o antigo c o moderno. Portanto, seu entendimento passa necessariamente pela análise da instrumentalização que Nabuco fez da história.

Para identificar e qualificar a escravidảo vivida no Brasil, o autor minimizou a ação do tempo. Recorreu ora ao Antigo Regime com seus atributos (feudalismo, servidão, aristocracia, monopólio), ora à Roma Republicana e suas instituiçócs (o latifúndio, a escravidão, a aristocracia, a plebc)(29). Esta aproximaçảo histórica, somada ao argumento de que a escravidão no Brasil assumiu a mesma performance por trezentos anos, mais a identificação de sua natureza com os traços da moralidade, fez com que ela aparecesse comouma prática universal inerente à natureza humana. Assim, Escravidāoc Abolicionismo tornaram-se práticas recorrentes da história da Humanidade que se negam: enquanto um é aparentado da civilização c da bondade, a outra é sinônimo de maldade c barbáric.

Também o Abolicionismo foi, conforme já vimos, qualificado a partir de semelhanças com o passado. Foi deste mesmo passado que Nabuco resgatou propostas e argumentos para compor seu projeto político. A luta pelo progresso, pela construçảo/regeneraçáo da naçáo, pelo laissez-faire e contra o monopólio e a escravidão, sáo temas inscritos nos clássicos liberais desde o século XVIII. Por sua vez, a lei agrária, o imposto territorial, a pequena propriedade, a reeducação pelo trabalho e a reforma/revoluçảo aparecem em diferentes momentos e falas de políticos brasileiros do século XIX (30). Na verdade, o autor procurou, em momentos distintos da história universal e da naçâio, temas, argumentos

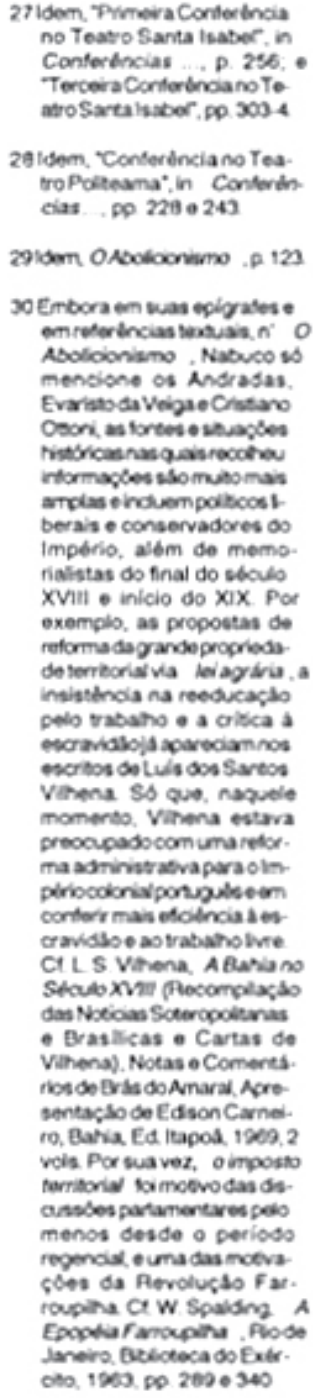


31 Una andise detahada da anacto de Nabuco de Na. vio - dos loerais cernambucanos nevte peri. odo fol leita por I A Usaron 10 inptrio do Progresso: a Aevolucso Pration em Pernemouco (ts42-1855) Sas Pavlo Bras lense. 1947

320 propetoreformsts conser. rascremerpiu nas elevisdes cernambucanas de 1840 47. 48. - ficou magitral. rente rejustraso nas pap. nas da Revists O Progres.

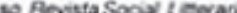
- Scimtica Precte. Typ do uanoel Figueros de faria. 1806 -48) Howe irterctm. @io de matinas erte evts revista e ojorna OLdado. cutoredator era vatumente bat Thomas Nabuce of Navio Eles autramingos

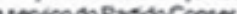
a lervico do Pa sobconser. vasor nas camparkas te. oras de tous a rees

$33 \mathrm{C}$ i A Marson Einte a Versemie a Puzbo Pepre. sereagles da Revolupiso na Pelicica Pernambucana.

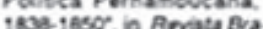
sleva de Histhis SboPay lo, $10(20), p e$ 172 210 , mav so- apo/ioni Peforma e Re. volusbio)

34En 1022 a supresabo da Le de Sesmarias tornovas ter. ras antes pertencentes a ras antes pertencentes à slos brasileires. que as coucaram racidamerce. Em 189 aboliu-se a Le dos Uacgados ato out tas. Quevics tiens des grandes. guroves tens das gandes.

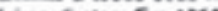

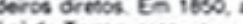
Lei de Terras procurou re. plariza as pesses que humam se constsuldo a gartir da indectendincia Das restricdes colonisis. we scara on pendino acteretudo oer interesse prefinos, justarterte aque. la que mantina a proprie. dase da terra e de seus pro. dact a saviodan hicotecas Contra ela bradurancescon. serradores en 1840, os randes procriativios gociantes no Coogresso a gicola do Pecite en 1070 - Nabuco em 1800 ss Com relapblo descravidba ombo a acorts a imoont hoi das mesdas tomadas contra cla Nabuco mininita ca ie.

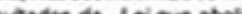
velados da Ler que aboli otrifoo (185O). da Leide 28 de setembro de 1871 . - es. pecialmente das alforrias pertaviares cletias por pe. cils ou por condiclo, ove ce orolimeram a partic de ivi. Ver Peter Gisentero Treastore Ficando Ume as N M Tomas - Campinas no Stculo $x \mathrm{x}$, in Homene Eaquec: dos. Campinas. Editora Unicane, 1980

35 I Nabuce, Sepunda Con ferthola no Teabro Santa incer, 11. 11. 18are in Con fertnolas De. 270., e propostas que, separados de seu contexto de origem, foram recriados para dar vida a um projeto inédito, intrincado na política da década de 1880 . Neste passado, Nabuco deteve. se mais demoradamente na política pernambucana entre osanos de 1840 e 1850 , momento em que o juiz José Thomaz Nabuco de Araújo, seu pai, atuou intensamente no partido conservador. Ali encontrou, já sistematizadas, idéias que eram recorrentes nos debates políticos e com elas construiu o projeto Abolicionista. Dos liberais, emprestou a "política de conciliação", a proposta de supremacia da Cämara sobre oSenado, osufrágiouniversal, a crítica à centralização e ao monopólio da aristocracia/oligarquia sobre o Estado, o princípio do federalismo e a proposta de "completar" a independência brasileira (31). Dos conservadores, apropriou o empenho em divulgar o verdadeiro liberalismo, o laissezfaire, a crítica aos correspondentes, a lei agrária, o impostoterritorial, a formação da classe média, a reeducaçáo política das elites e dos proletários, a idéia de construir um partidoque, superior aos existentes, estivesse preocupado tåo-somente com a nação e o "bem comum" (32). Curiosamente, os argumentos mais contundentes de Nabuco - a proposta de uma reforma/revoluçăo e a imagem da sociedade brasileira fundada nolatifúndio, na servidão e na escravidâo-eram, em 1840 , disputados tanto pelos liberais quanto pelos republicanos e conservadores (33).

Evidentemente, naquele momento, tais proposiçốes serviam a outros fins mais ime. diatos que foram alcançados, tais como aboliçáo do tráfico de escravos e a promulgação da Lei de Terras, metas que Nabuco ignorou (a Lei de Terras) ou atenuou (abolição do tráfico). Foi csse "esquecimento" e mais alguns outros que tornaram a escravidăo c a socicdade brasileira imagens petrificadas no tempo. A uniformização do tempo vividoc o ocultamento dos ganhos já obtidos pelo projeto liberal - a emancipação política, a superaçáo da legislação que restringia o acesso à propriedade e a sua circulação, e mesmo as vitórias contra a escravidão(34)-foram medidas ditadas pela necessidade de agigantar o tema que, assim, incorporou todos os atributos do Antigo Regime e se tornou a origem de todos os problemas da sociedade brasileira; e de engrandecer a missão política do projeto abolicionista $\mathrm{c}$ de seu autor.

Outroprocedimentoque contribuiu para a projeção da escravidão foioobscurecimento de seu lugar de origem: a política. Embora tenha preservado o conceito de monopólio, ao invés de situá-lo em seu campo originário, Nabucoalocou-o nodomínio de um opacoe abrangente social.

"Ela começou por ser um regime de trabalhoagrícola.(...) Mas esse regime de trabalho agrícola, só podendo ser mantido pela supressão da natureza humana, precisava de cercar-se de proteçōes especiaise de viver num meio à parte, fechado e todo seu, e daí resultou um sistema territorial, caracterizado pelo monopólioda terra e pela clausura dos trabalhadores. Tal sistema deu origem (...) à apariçäo e gradualmente ao crescimen to de uma populaçăo livre (...), miserável e dependente no mesmo grau que o escravo. Eis aí a escravidåo agrícola e territorial.

Mas como se vê, com uma instituição que possui o solo, o trabalho agrícola e a população livre, o mal nảo podia circunscrever-se: a escravidão, de sistema agrícola e territorial, tornou-se um regime social e estendeu o seu domínio por toda a parte (...." (35).

Entretanto, é interessante notar que, se o social é um conceito nebuloso, o lugar da política é, por sua vez, movediço. Se neste momento mencionado(assim como no texto do Abolicionismo), ela aparece dissolvida no social, $\mathrm{cm}$ outra passagem deste mesmo discurso oautor cinde totalmente os doiscampos. Quandodeclara seu desencanto com as "reformas políticas"e reivindica para si o estatuto de "reformador social"- um dos seus argumentos de maior apelo popular - Nabuco comenta:

"Em tal regime, o que conseguem reformas políticas? Muitas têm sidotentadas, algumas feitas; mas com que resultado?

As reformas políticas exprimem em nosso país cinqüenta anos de esperanças populares atraiçoadas.

Fez-se, por exemplo, uma reforma eleitoral, elevando-se o censo, no intuito de obter uma manifestação mais sincera e mais veridica da vontade nacional; e o resultado foi que oParlamentoconverteu-se numverdadeiro Congressoagrícola; foique, por alguns 


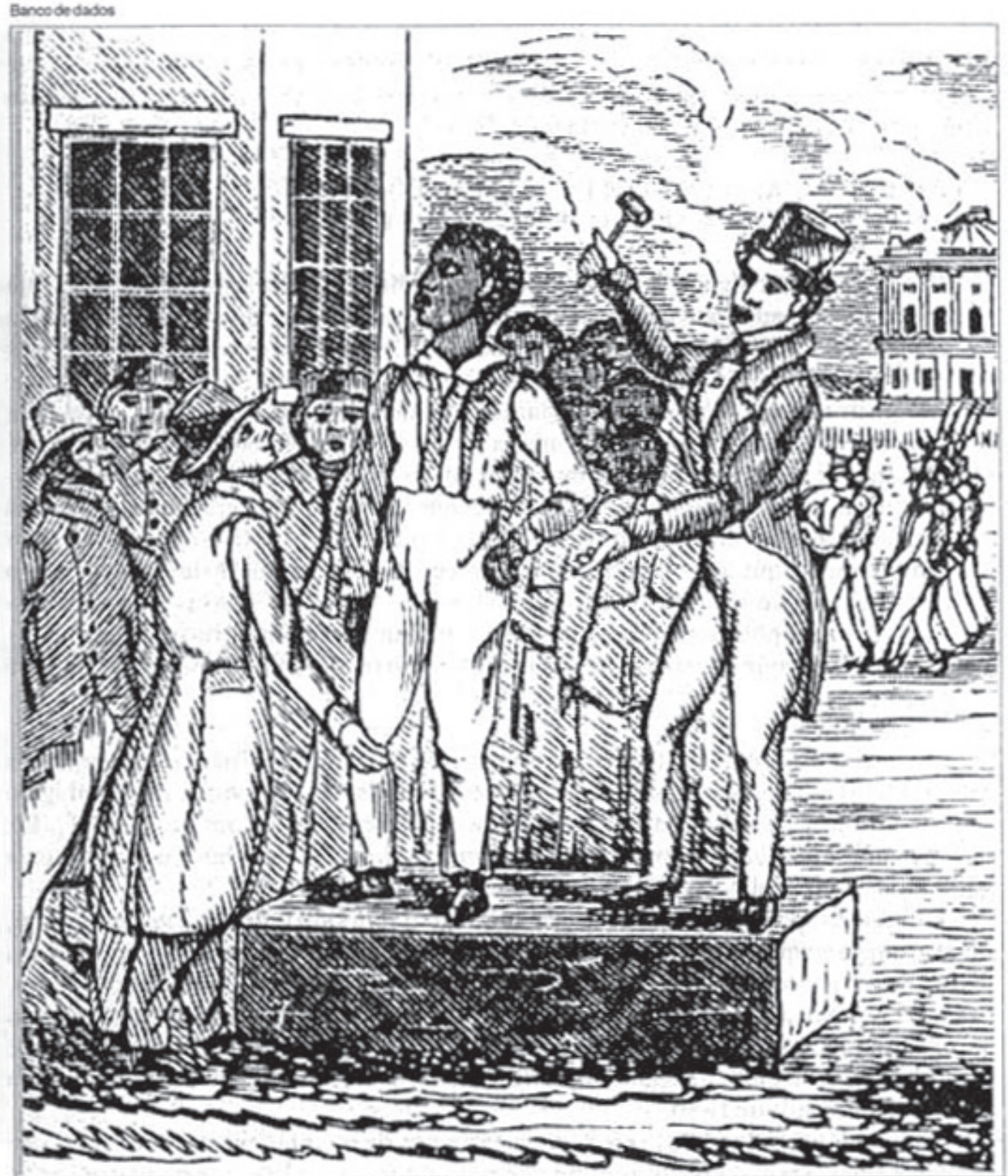

lugares dados às cidades que representam a inteligência e a intuiçáo nacional, cem foram dados em penhor à escravidâo, entregues ao monopólio territorial (...).

Tudo isto mostra que entre nós as reformas políticas não têm base $\mathrm{e}$ portanto nāo têm ainda razão de precedência, e que as reformas de que imediatamente necessitamos são reformas sociais que levantem o nível do nosso povo, que o forcem aotrabalho, e dêem em resultado obem-estar $\mathrm{e}$ a independência que absolutamente nảo existem e de que nenhum governo ainda cogitou para a naçăo brasileira.(...) Sim, senhores, precisamos (...) sobretudo de duas grandes reformas: a abolição completa, civil e territorial, da escravidāo, que é o meio da integraçāo da nossa Pátria, e oderramamento universal da instrução(...)"(36).

Todavia, o mais eficiente artifício para o engrandecimento da escravidão foi tornar a luta Abolicionismo versus Escravidão um drama histórico, uma epopéia trágica, como, por exemplo, a epopéia hebraica (37). Tornaram-se personagens de um drama universal, vivido pela humanidade em geral e pela sociedade brasileira em particular, representados por imagens recolhidas à literatura - ela se espelhou no Minotauro, na Medusa - ou ao imaginário romântico - ele é o dia, ela a noite (38). Os escravos, os "proletários" e a naçāo se transfiguraram em vítimas indefesas, reféns que só se rebelam em atos esporádicos e desesperados, seres passivos, "órfảos dodestino", oprimidos por déspotas maus, egoistas
36 idem, Bidem. ph. $272-4$

37 idem, bideen, pe 260-1. Em 1675 , Nabuco ja havia escr. to um outro drama hiatson. co. Aletembrandoetse episs. do. comertou as relaches do. comentiou as rolapoes entre palicia a a 707, entreguei-me a composicato de umdrama, em verso francts. cuja tactura me absorves durante mais de dois anos A lidtia do meu drama era

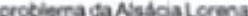
proviomaciansacalcrena polveo da minta inaginacla A politica (-) temlados ainda indetridos que cons. nam com a ante, a relojito a flonota, iato b. para falar a inguagen hegeliana com as tits esteras em que so marilesta o espirho domundo". I Nabuco, Mina For. macdo, p. 7 . Sobre as me diços entre tiseratura e políca ver tambdim o cas 15. De 127-8. aldm de ind. meras outras passagens ao longo do texto.

$38 \mathrm{I} 1 \mathrm{sem}$ O Abolicionieno. P 14\% Conterdncias - D. 26? A recorrencia a fontes iseriblas acontece mutas vezes. $\mathrm{N}^{\prime} \mathrm{O}$ Abolicionismo menciona A Cabara do Pa Tonds de Mrs A Saove to Th: A Traghte no Me , de 4n. A ragada no pas a cador de Veneza de cador de Veneza de se ainda a "O Navatagio da Medusa', pintura de Gericault (p. 77 ). Figuras do imaginario romartico abrem opbol tolonismo witatiour dans vofre Ame ains ove su vos trontsla ndtre est une nut où nous nous dgarons" Ramartine. Toussaint Laverture) 1. Scbre a dimen sso conservadora do imag. nafrio romantico ver Provero Pomano conser. Roberno Alomano, Conser vadorismo Romblece OnPam do Totaltariano; S 


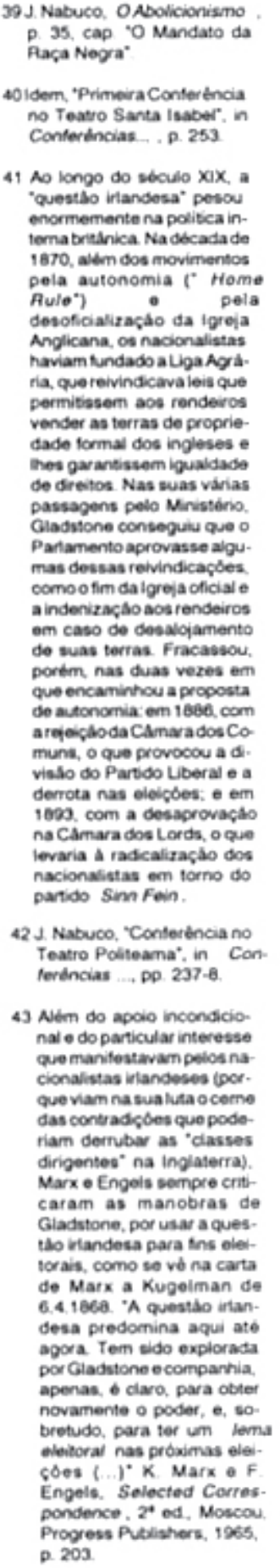

e degenerados. Eos abolicionistas - liberais autênticos - sāo homens bons, dedicados a uma grande causa: emancipar todos os escravos do Brasil, cumprindo assim um "mandato" que a raça negra lhes conferiu, uma vez que a sociedade brasileira nāopermite que ela atue em causa própria, nem pela lei, nem pela força (39).

\section{POLÍTICA, HISTÓRIA E MEMÓRIA: OS VÍNCULOS COM O PRESENTE}

"Infelizmente, senhores, nós lutamos contra a indiferença que a nossa causa encontra entre essas mesmas classes que deveriam ser nossas aliadas e que a escravidảo reduz ao mais infeliz estado de miséria e dependência (...) Por acaso os homens de cor, filhos e netos de escravos (...) têm aderido ao nosso movimento com a dedicaçảo e a lealdade que era de esperar dos herdeiros de tantos sofrimentos? Nâo! Eles năo se atrevem a fazer causa comum com os abolicionistas e muitos são encontrados do lado contrário! Tomemos uma grande classe, os moradores do campo, os que vivem espalhados pelo interior $\mathrm{em}$ pobres cabanas, os homens livres que trabalham $\mathrm{em}$ terras alheias. Dāoeles sinal algum de compreender o alcance desta propaganda (...) Nâosenhores, eles não compreendem que o abolicionismo é o começo da propriedade do lavrador (...) Não é conosco, os que levantamos o gritode - aboliçäo - que se unem essas vítimas impassíveis do monopólio territorial; é com os outros que levantam o grito de escravidăoda escravidăo que as esmaga sem que elas o saibam por que as comprime desde $o$ berço"(...)(40).

Ocomentário de Nabuco tambémé dramático. Os “oprimidos” nâo compreenderam a dedicaçăo daqueles que quiseram redimi-los. Completava-se, assim, o quadro trágico (para as vítimas) e heróico (para os libertadores). Ea recusa da "vítima" em ser salva faz o historiador se perguntar: comodeveria interpretar as imagens que Nabuco projetou para o liberalismo, a escravidāo e a sociedade brasileira do século XIX?

Diferentes aproximaçōes e usos destas imagens têm sido feitos ao longo do tempo, porém, qualquer que seja a circunstância, é imprescindivel que se considere a origem dos textos: nasceram como projeto, no interior de um acirrado confronto entre conservadores, liberais c republicanos, na disputa pela primazia de encaminhar a solução para a "questăo servil" c para a regeneração ou superação do regime. Antes de tudo, as proposiçổes de Nabucosãoum magnífico argumentopolítico, um refinado testemunhodo cmbate vivido no Brasil na década de 1880 .

Além das consideraçōes já feitas, gostaríamos de apontar outras evidências que fundamentam esta percepçăo: as motivaçōes do autor na escolha do tema liberalismo e escravidão; os possíveis compromissos de suas propostas, e a correspondência entre sua interpretaçảo e algumas ocorrências da história do Brasil no século XIX.

Adeterminaçâode instituir-se um "reformador social" foi inspirada em exemplos de abolicionistas e estadistas ingleses $\mathrm{c}$ americanos (que aparecem nas epígrafes e no texto doAbolicionismo) e, sobretudo, na política inglesa contemporânea, mais especialmente na atuaçăo de Gladstone na questâoirlandesa (41). Nabuco instrumentalizou esta experiência adequando-a à interpretação que criou para a escravidâo:

“Eu quero apenas citar um exemplo análogo de que fui testemunha dia por dia: o exemplo de Gladstone com a questảo irlandesa.

Quando o ilustre estadista liberal (...) achava-se a braços com essa grande reforma agrária irlandesa que afinal arrancou do Parlamentoestupefato, os crimes de rendeiros contra proprictários na Irlanda, ou contra os agentes do proprictário (...) multiplicavam-se de modo assustador. Qualquer outro homem teria desanimado. Mas Gladstone, quando se the dizia 'Nâo é este o momento de concessōes: o país está anarquizado,o terror está de posse da Irlanda, o dever dogovernoé restabelecer a ordem' (...) respondia com a mesma calma e sangue frio que eu quisera que os nossos estadistas se mostrassem capazes: 'Sim, é preciso reprimir a desordem e fazer triunfar a legalidade; mas esses crimes são o resultado de um regime injusto que a agitaçảo está explorando (...) para que a autoridade restabeleça o dominio da lei de modo permanente é indispensável destruir a origem de tais perturbaçōes. É preciso portantoque voteis a reforma 
para que a ordem pública na Irlanda assente sobre o interesse dessas mesmas classes que hoje lhes são hostis'. Essa é a linguagem de um verdadeiro estadista encarregado de uma reforma social de futuro (...). Eacreditai-me, senhores, o estado da Irlanda cra muito sério e grave, infinitamente mais sério c grave do que o do nosso país, onde a estatística havia de mostrar, se fosse feita, que a criminalidade não é, como foi na Irlanda, dos oprimidos contra os opressores, mas que toda dos opressores contra os oprimidos!"(42).

A simples identificação com Gladstone já indica uma pista, uma vez que ele recebeu muitas críticas de seus contemporâneos, e dentre elas a de manipulação eleitoral feita por Marx e Engels (43). Estaria também Nabuco espelhando esta faceta do político liberal, ao fazer da "causa dos escravos" um sucedâneo da questão irlandesa? Que razões poderiam tê-lo levado a agigantar a escravidāo num momento em que ela já estava sendo superada na maior parte das províncias do Império?

A descoberta de possíveis explicações sugere a retomada do projeto de Nabuco, assim como a identificaçāo de seus interlocutores. Ele se posicionou contra o "monopólio escravista", ou o predomínio dos "agricultores do Sul" no Parlamento; a emancipaçăo dos escravos com indenização; a imigração subsidiada; os correspondentes. Declarou-se $a$ favor da emancipaçāo imediata sem indenização; da imposição do trabalhopara os homens livres pobres; da superaçāodos direitos que preservavam a terra da execução das hipotecas; do fim da hegemonia dos correspondentes nos negócios; das reformas que regenerassem a monarquia e detivessem o avanço republicano sobre os outros partidos. Estas propostas o aproximam muito das deliberaçōes dos grandes agricultores que se reuniram no Congresso Agrícola do Recifc (44) em reação aos fazendeiros paulistas e fluminenses que apoiavam justamente as medidas criticadas por Nabuco. Nesse sentido, a expressâo "monopólio escravagista" designava estes agricultores, em māos de quem estavam os maiores plantéis de escravos do Brasil. Para enfrentá-los, batalhando possivelmente em prol da modernizaçăo da empresa açucareira no Norte, Nabuco engrandeceu a escravidāo e generalizou esta situação idealizada para uma indefinida "casta de senhores" que incluía todos os proprietários no presente e no passado. Tal artifício serviu ainda para desarmar a crítica republicana à monarquia parlamentar: “A grande questāo da democracia brasileira nãoé a monarquia, é a escravidāo" (45).

Porém, o projeto abolicionista é ambíguo, já que outras reivindicaçōes nele contidas parecem aproximá-loda naçāo de proletários e dos escravos: a defesa da emancipaçāo, do voto direto para os alfabetizados, da lei agrária, do imposto territorial, do direito ao trabatho, da pequena propriedade. Seria possível conciliar interesses tão díspares? Estariam os "proletários" de acordo com o papel a eles reservado na nação? O lamento de Nabuco e o comportamento concreto dos personagens insinuam que nâo. Falando pelos pequenos emédios proprietários do Norte (categoria inexistente noquadrosocial traçadopor Nabuco) noCongresso do Recife, Henrique Augusto Milet defendeu os correspondentes, os tradicionais direitos dos senhores de engenho o o subsídiodo Estado para que estes proprietários pudessem arcar com os custos do trabalho livre (46). Por sua vez, moradores e rendeiros negaram-se, por duas vezes ao longo do século XIX, a aceitar o avanço do progresso. Em 1851 , no Roncoda Abelha (47) repeliram decretos imperiais que obrigavam o censo e o registro de nascimentos e óbitos, temendo que - diante da recente aboliçāo do tráfico - o Estado os recrutasse para desempenhar o trabalho na lavoura até então executado por escravos; e em 1875, na Revolta do Quebra-Quilos (48) investiram contra as determinaçöes que alteravam o sistema de pesos e medidas e os regulamentos que barravam seu acesso às feiras. Ainda, na Revolução Praieira (1848-49), artistas e proprictários de pequenos e médios banguês e seus rendeiros e moradores recorreram às armas e enfrentaram uma guerra civil para negar, justamente, o programa progressista que forneceu a Nabuco as propostas mais "revolucionárias" do seu Abolicionismo (49).

Todavia, além destas dissonâncias, é importante lembrar a rebeldia, na vida real, dos principais personagens da luta Abolicionismo versus Escravidão. Os escravos com suas negociaçōes e resistências cotidianas, dentro e fora da lei, teimosamente destoaram da "passividade" e do martírio que seu papel lhes conferia (50). Eos signatários do "monopólio escravagista" certamente se insurgiram contra a "inércia" que o textode Nabucolhes impingira no grande drama vivido pela sociedade brasileira do século XIX(51).

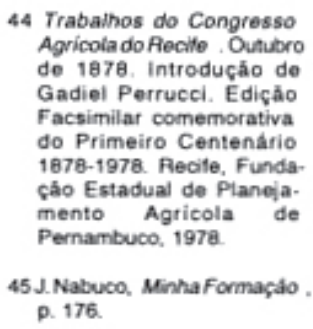

46 Trabalhos do Congresso Agricola do Recifo. PQ. 119 31. H. A. Milet, A Lavoura da Canna de Assucar . Recifo, Jornal do Recife, 1881

47 I. A. Marson, O Império do Progresso. p. 415 e segs. "Trebalho Livre e Progres. so", in Aevista Brasileira de História, Sáo Paulo, 4(7), pp B1.93, 1984

48 H. A. Milot, Os Quebra-Quillos e a Crise da Lavoura Pecife, Jornal do Recife, 1876; Armando Souto Maior, Quebra-Quilos: Lutas Sociais no Outono do impé. rio, Sào Pajo. Ed Naciona Rrasilia INI Pecite Inst. Mrasitin int, Rocite, Inst. Joaquim Nabuco de Pesqu. sas Sociais, 1978

49 1. A. Marson, $O$ Imperio do Progresso: a Revoluça Prajeira em Pernambuco (1842-1855), Såo Paulo. Brasiliense, 19e?

50 As imagens classicas cria. das por Nabuco para a es cravidáo vếm sendo revi. sitadas no Brasil por historiadores e sociólogos, desde a década de 60 . Desen. de a decada de 60 Desen. historiografia da escravi. dảo, que desde aquela épo. ca vem fazendo revisdes sucessivas destas imagens

Os últimos trabalhos corn este cojetevo ja publicados ado: Cellia M M Azevedo. Onda Negra Modo Rranco. Onda Negra. Modo Branco Ailo de Janeiro, Paz e Terra, 1987: Silvia Hunold Lara, Campos da violencia: Es. cravos e Senhores na Capl. tania do $A$. de Janeiro (1750. 1806). Pio de Janeiro, Paz e Terra, 1988; M Helena P. T Machado, Crime e Escravi. dilo: Trabaho, Luta, flesistencia nas Lavouras Paulistas. 1830-1888, Sâo Paulo, Brasiliense, 1987; Leila M. Agranti, O Foito Ausente: Estudos sobve a Escravidajo Urbana no $A$. de Janeiro 1808-1822, Petropolis, Vozes, 1986; Stuart B. Schwartz, Segredos inter. nos: Engenhos a Escravos na Sociedade Colonial, Trad. Laura T. Motta, Sáo Paulo, Cia das Letras, 1988: Sidner Chalhoub. Visó. - Sidnoy Chalhoub, Visóes da Liberdade; uma Historia das Úttimas Décadas da Escravidiso na Conte, Sáo Paulo, Cla das Letras, 1900.

51 Ct. M. Stella M Bresciani, Li beralismo: Ideologia e Con. troie Social fum estudo sobre S. Paulo entre 1850. 1910). Tese de Doutoramento. Sáo Paula. FFLCH. USP, 1976, mimeo:; - Repenser le marché du travalitre dansle Brtesid XIX $X^{\circ}$ sidete $0^{*}$ Gans le Bresil du 9:120-137, octobre/1992. 